\title{
THE RELATIONSHIP BETWEEN PERSONALITY AND BEING EXPOSED TO WORKPLACE BULLYING OR MOBBING
}

\author{
*Nevin DENIZ \\ **Oznur GULEN ERTOSUN \\ *Marmara University \\ **Gebze Institute of Technology
}

\begin{abstract}
Workplace bullying which is frequently in discussion at organizations and academia, and effects badly quality of both work and private life of victims and witnesses can be prevent if the antecedents of the phenomenon is known. Some researchers stress on organizational and individual antecedents while some others refuse personality factor. School-based studies found significant relationship between personality and bullying which is the start point for workplace bullying studies about personality factors. The study is done in order to investigate the relation between workplace bullying and personality of employee being exposed to such behaviors that is stated as "victim". Because there are few academic studies in Turkey about workplace bullying, which is just new and less known issue and personality of victim, by investigating international researches, personality of victim is found to have taken into consideration as one of antecedent of workplace bullying. A cross sectional survey is done in a single company in order to investigate the relationship between variables and similarly to the international researches significant correlations found.
\end{abstract}

Keywords: Workplace Bullying; Mobbing; Personality

\section{INTRODUCTION}

While explaining antecedents of workplace bullying most researchers stress on organizational and social factors; Leymann indicated that organization of work and quality of leadership are the main antecedents of workplace bullying (Einarsen, Hoel, Zapf, Cooper, 2003, p.165), studies by Keashly and Jagatic (2000) and Varita (1996) suggest that communication and cooperation problems, low morale and negative social climate are the main organizational causes of bullying, another study is done by Hoel and Salin (2003) reports that at the condition wherein job and promotion opportunities decrease and competition, pressure and responsibilities increase, bullying find place itself (Beswick, Gore, Palferman,2006, p.21-23).Varita (2001), Hoel \& Cooper (2000) found relationship between bullying and 'high workload (Beswick, Gore, Palferman,2006, p.24) and Rayner (1997a) found in his survey similar results (ACPR, p.16). Beside these such as, "role ambiguity and role conflict" (Beswick, Gore, Palferman, 2006, p.23), "low status workers" (Hodson, Roscigno, Lopez, 2006, p.407) and "low control over time" (Beswick, Gore, Palferman, 2006, p.22; ACPR, p.16), several variables are investigated as antecedents of workplace bullying.

However investigating victims' personality is a divisive issue for researchers; for example Leymann strongly against the idea that personality of a person can be reason for being victim because victims develop changes in personality due to workplace bullying; the symptoms of bullying are misunderstood and interpreted as being that which the individual brings into the organization in the first place (Coyne, Seigne, Randall, 2000, p.337). Brodsky says that if organizational climate doesn't permit, workplace bullying can't be occur (Shin, 2005, p.11.). According to Zapf; the responses of the target can be thought at least in the early phases of conflict, but he stress on not to blaming 
victim (Salin, Ekonomi Och Samhalle, 2003, p.18).

Contrastly to these, school based bullying studies (e.g. Olweus, 1993) found victims' personality as an effective factor (Einarsen, Hoel, Zapf, Cooper, 2003, p.165), and Randall (1997) said that these results can be possible for adult bullying (Coyne, Seigne, Randall, 2000, p.337). According to Einarsen and others organizational factors naturally important (Einarsen, Hoel, Zapf, Cooper, 2003, p.165) but can't explain the whole of the picture without individual side (Rayner, Hoel, 1997, p.186). The experiences of being bullied which is a cognitive process of evaluation affected by both situational and personality variables (Matthiesen, Einarsen, 2001, p.470), hence personality of victim is investigated in this study.

Firstly, literature is reviewed, research model is structured in the light of the literature, personality is the independent variable, workplace bullying or mobbing is the dependent variable and demographic variables are investigated in the research model then hypothesis are developed. After main information about the subject is given and discussed their theoretical implications in the study, to find answer to the research question "Is there a significant relation between being exposed to workplace bullying and victim's personality”, statistical analysis are done. Finally, research findings obtained, and then compared with recent researches.

\section{WORKPLACE BULLYING AND PERSONALITY}

\section{Workplace Bullying}

Heinz Leymann used the term "mobbing" for the first time to define specific type of aggressive behaviors such as hostile and unethical communication styles directed to one employee at the workplace According to him physical actions can be named as "workplace bullying" (Davenport, Schwartz, Eliot, 2000, p.14). However some of the researchers define two types of bullying behaviors: physical which contains physically pressure or assault their victims in some way; secondly psychological bullying that bullies use subtle, underhand strategies to undermine their victims, mentally or emotionally (Richards, Freeman, p.7).

Some researchers used the term mobbing to explain the phenomenon (like Leymann, Einarsen), some others define mobbing as a type of bullying (Tehrani, 2005, p.9), another approach to the terminology is that when the action occurs one-on-one, calls it bullying, harassment or abuse; but if it happen by the others participation then is defined as mobbing (Martin, 2001, p.31). In addition to these, like workplace aggression- Neuman \& Baron, 2003 (Fox, 2005, p.439) and abusive disrespectHornstein, 1996 (Blase, 2002, p.674) different terms are used in the literature. Generally while European authors prefer the term bullying, Americans use both mobbing and bullying and Sweden has used victimization for the same phenomenon. Different terms are used in Turkey as well but mobbing is seen usually agreed for Turkish literature.

However workplace bullying (Westhues, 2006, p.1; Douglas, 2001, p.4) is used largely in the international studies and general idea accepting all terms synonym, in this study the way followed and workplace bullying is used to define the action.

The following definition of workplace bullying seems to be widely agreed upon (Einarsen et al., 2003, Einarsen, 2000; Einarsen and Skogstad, 1966; Leymann, 1993b; Zapf, 1999a) and it is accepted for this study: Bullying at work means; “...harassing, offending, socially excluding someone or negatively affecting someone's work tasks. In order for the label bullying (or mobbing) to be applied to a particular activity, interaction or process it has to occur repeatedly and regularly (e.g. weekly) and over a period of time (e.g. about six months). Bullying is an escalating process in the course of which the person confronted ends up in an inferior position and becomes the target of 
systematic negative social acts. A conflict cannot be called bullying if the incident is an isolated event or if two parties of approximately equal 'strength' are in conflict" (Einarsen, Hoel, Zapf, Cooper, 2003, p.103).

\section{Personality}

In spite of lack of universally accepted definition of personality (Ewen, 1998, p.1) most of investigators agree by the following definition; and it is the accepted definition for this study; "personality is a dynamic and organized set of characteristics possessed by a person that uniquely influences his or her cognitions, motivations, and behaviors in various situations. It can also be thought of a psychological construct- a complex abstraction that encompasses the person's unique genetic background (except in the case of identical twins) and learning history and the ways in which these factors influence his or her responses to various environments or situations. So many investigators regard the study of personality as primarily the scientific analysis of individual differences. That account for why and how people react uniquely, and often creatively, to various environmental or situational demands" (Rckyman, 2000, p.5-6).

\section{Prevalence of Workplace Bullying}

A range of studies has reported that there is a higher prevalence of bullying in public administration, health, social work, teaching and prison officers (Irish Taskforce on the prevention of Workplace Bullying, 2001; Leymann, 1996) (ACPR, p.9) our sample is one of risk sectors.

Direction of workplace bullying: Researches on the prevalence of workplace mobbing showed that downward mobbing-mobbing by a supervisor against a subordinate - is the most prevalent (Vanderkerckhove, 2006, p.53), in the study 60\% of those self-identifying as bullied reported one or more supervisors as the perpetrators and research found that bullying from supervisors is more hurtful than from co-workers (Keashly \& Neuman,2005; Keashly, Neuman, \& Burnazi,2004; Schat et al.,2006) (Sandvik, 2006, p.31).

Gender: Most large-scale studies have reported fairly equal victimization rates for both men and women (Einarsen \& Skogstad, 1996; Hoel \& Cooper, 2000; Leymann 1992a; Varita, 1996). Gender reveals is the position and gender of bullies; generally men are bullied by male supervisors, women report being bullied by both superiors and colleagues and by both men and women in approximately equal proportions (Eriksen \& Skogstad, 1996; Hoel \& Cooper, 2000; Leymann, 1992b) (Salin, 2005, p.2). Most of sexual harassment derogates and rejects victims based on sex rather than solicits sexual relations with them (cf. Fitzgerald et al., 1988; Schultz, 1998; U.S. Merit Systems Protection Board, 1981, 1988, 1995). Men that endorse male dominance are more likely to harass the opposite sex, and the person who is in such environment exposes to bullying more frequently (Berdahl, 2007, p.641).

Age: Some researchers found no significant difference between young and old employees in frequency of being bullied (Quine 2002). However Einarsen and Rankes (1997), Hoel and Cooper (2000) and Quine (1999) discovered that employees at young ages were at more risk of being a victim. Contrastly to these findings, it was reported at Einarsen and Skogstad's (1996) study that older employees were exposed to being bullying more that the younger employees (Einarsen \& Skogstad, 1996, p.195).

Organizational status: Researches about the role of organizational status indicated different results. In a Swedish nationwide study, senior managers were over-represented among bullying victims; the differences with regard to hierarchical position were not statistically significant (Leymann, 1992a). Beside this, in a large Finnish survey, upper white-collar employees reported somewhat more bullying than lower white-collar employees or workers (Piirainen et al., 2000). 
Contrastly Hoel, Cooper and Faragher (2001) based on a large-scale study in the UK although they found few differences in the experience of self-reported bullying between employees in different hierarchical positions; they indicated that workers and supervisors were more often exposed to predefined negative acts than managers.(Salin, 2005, p.2).

Lead of the studies above cited, demographic properties are asked to the participants. Differences between demographic properties and being exposed to workplace bullying are investigated by the hypothesis. " $\mathrm{H}_{1}$ : There is any difference depending on demographic variables in being exposed to workplace bullying".

\section{The Relationship between Workplace Bullying and Victim's Personality}

There are a few structured empirical researches about personality of victim (Coyne, Seigne, Randall, 2000, p.337), some researchers with different methods or scales found similar victim profiles, some others found no difference between being victim and non-victim. In the following some leading researches and their findings take place and main hypothesis is developed on the basis of the literature.

Brodsky (1976, as cited in Varita, 1996) by looking at a working context described victims as conscientious, literal-minded, paranoid, rigid, and compulsive. According to Einarsen et al. (1994) in a Norwegian survey it is found that victims coping and conflict management skills are lower than others as well as shyness contributed to being bullied. As another research Varita (1996) in a survey in Finland reported that victims were higher in neuroticism than non-victims but when work environment and climate were controlled the relation was reduced. 16PF personality profiles in a sample of 30 self-selecting Irish workplace victims were found lower in emotional stability and dominance and higher in anxiety, apprehension, and sensitivity than non-victims. Another study Zapf (1999) in German sample found that victims of bullying had pre-existing symptoms of anxiety and depression and lower social skills than others, and avoided conflict by tending to give away (Coyne, Seigne, Randall,2000, p.337). In the study of Coyne, Seigne, and Randall (2000), 60 Irish victims of bullying, using a comprehensive measure of personality based on a Five-Factor model, is found less extroverted and independent than control sample of non-victims, in addition to this, victims are more unstable and conscientious. According to Thylefors (1987) victims could be characterized by the fact that in conflict situations they reacted in a more active and aggressive way than non-victims. Victims of bullying at work have been shown to portray a poor self-image as well as being anxious in social situations (Einarsen, Raknes, Matthiesen, \& Hellesey, 1994) (Matthiesen, Einarsen, 2001, p.469).

In addition to these researches; according to Davenport et al., interviews with victims show that the victims are exceptional individuals. They have positive qualities such as intelligence, competence, creativity, integrity, accomplishment and dedication. They are emotionally intelligent as Daniel Goleman's words. Victims have a high degree of loyalty towards their organizations and highly identified with their work or by their work. Because they are creativity, they promote new ideas which may challenge others and they are seen a threat to high-positions, so they may seen target for bullying. Westhues, found in his study that the victims who were ganged up on tend to be trusting, naïve, politically inept, high achievers (Davenport, Schwartz, Eliot, 2000, p.70). Jacqueline Randle in his study on healthcare professionals found victims as clear thinking and proactive individuals (Randle, 2006, p.26).

Contrastly to the findings, Gandolfo's (1995) study has utilized comprehensive measures of personality. Gandolfo's sample is Americans who claimed compensation from insurance companies 
for harassment in the workplace. In the study victim's personality profiles were studied by means of MMPI-2 and compared with those of a control. In five of the ten personality dimensions an elevated personality was identified in the victims indicating severe psychological and emotional disturbance. The results for the non-harassed group were similar on four of these five scales in the study. Therefore in the study no significant difference between harassed and non-harassed was found (Matthiesen, Einarsen, p.469).

Victims and their spokespersons have claimed that bullying is mainly caused by the psychopathic personality of the bully (e.g. Field, 1996) (Einarsen, Hoel, Zapf, Cooper, 2003, p.165). However both bullies and victim's colleagues frequently report that the personality and manners of victim play important role in bullying (Einarsen, Raknes, Matthiesen, \& Hellesoy, 1994) (Matthiesen, Einarsen, p.470). Not a few researchers are agree on that victims react and affected by differently to similar workplace bullying conduct (Davenport, Schwartz, Eliot, 2000, p.39). Moreover some characteristics within an individual may predispose victims those to being bullied (Randall, 1997). They may be selected because of their personality (Varita, 1996) that is the predatory selected the victim because he sees the lack of social skills as well as tendency to avoid conflict (Zapf, 1999), inability to cope (Einarsen, 1999). In addition to these, victim may provoke the predatory by aggressive behaviors (Einarsen, 1994) these differences is thought by some researchers as relate to whether the victim experiences predatory or dispute-related bullying. At school-based bullying provocateur victims and specific personality types of victims are reported as well (Coyne, Seigne, Randall, 2000, p.337).

As well the victim's personality can't explain the bullying behavior; it is certain that personality effects how she or he experiences and interprets incidents and possibility of mastering the problems at work (Einarsen, 2000). Victim's personality may affect the degree of the negative behavior. As Lakey, Tardiff, \& Drew, 1994 stated that; although the experience of being exposed to bullying is based on a real situation, such an experience doesn't represent an objective description of the environment without the personality factor (Matthiesen, Einarsen, 2001, p.470).

After all, the main hypothesis " $\mathrm{H}_{2:}$ There is a significant relationship between personality and being exposed to workplace bullying or mobbing" is determined and investigated by questionnaire method.

\section{Figure1: Research Model}

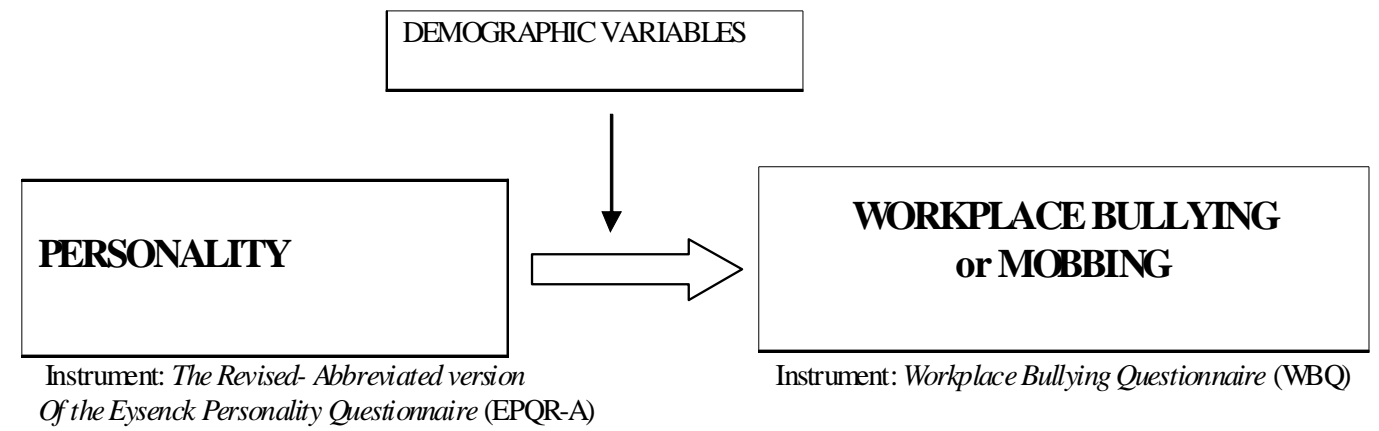

\section{RESEARCH DESIGN}

The research is applied in a company in order to provide the victim's to be in the same organizational conditions. The company's total employee number is 242 , and 186 valid questionnaires are used in the study. The conveniency sampling method was used. The questionnaires were prepared as hard copies and a link has prepared in order to send questionnaire 
through e-mail to the employees' of the company. Data was collected in June 2008. The questionnaire contains three parts; the first part is asking demographic properties of participants.

The second is about personality traits; in 1975 Eysenck \& Eysenck composed The Eysenck Personality Questionnaire (EPQ) (H. J. Eysenck \& S. B. G Eysenck, 1990, nu 22). Because originally the full version of Eysenck Personality Profiler with 440-item was too long, shorter versions were created. The Eysenck Personality Questionnaire- Short Form (EPQR-S) is developed in 1985 by Eysenck, Eysenck \& Barrett (Forrest, Lewis, Shevlin, 2000, p.580). Lastly Francis et al, in 1992 shorten to 24 questions; The Revised- Abbreviated version of the Eysenck Personality Questionnaire (EPQR-A). Some argues that the EPQR-A version's value is lower than the longers but it's acceptable and the main advantage of the questionnaire is that it is valuable when administration time is limited, and a relatively complete description of personality is required (Francis, Jackson,2004, p.1664) and it is translated to Turkish by Karanc1 et al. (Karanc1, 2007, p.2). The questionnaire contains three subscales (extroversion, neuroticism, psychoticism) and by a lie subscale was designed in order to hinder subjectivity at the answering period and controlling validity. All factors contain 6 questions, at total participants answer 24 questions for the scale and the answers were yes (1) - no (0) so the points for every factor was between 0 and 6 . By the cultural scales the validity and reliability for adopting Turkish literature was examined and the scale was found reliable and valid (Karanc1, 2007, p.7).

The third part of questionnaire assesses negative behaviors that are exposed in the workplace, which is Workplace Bullying Questionnaire (WBQ). The questionnaire contains 36 questions; it is designed by A. Dikmen and H. Sinangil by using the Leymann Inventory of Psychological TerrorizationLIPT (www.leymann.se), Einarsen et al's Negative Act Questionnaire- NAQ (Notelaers, Einarsen, Witte, Vermunt, 2006, p.290) and interviews with employees that exposed to negative behaviors at work (Dikmen, p.26). WBQ is designed as a five- point likert type, after a pilot analysis it reduced to four points (from "never" to "about daily"). The questionnaire also contains direction of workplace bullying, as "superiors", "colleagues" and "subordinates, if participants exposed to the workplace bullying it was asked from whom by the part.

\section{DATA ANALYSIS AND HYPOTHESES TEST RESULTS Demographic Distribution of the Sample}

Demographic profile was determined by frequency analysis; male $(53,2 \%)$, female $(46,8 \%)$, age allocations are below $30(68.3 \%)$, between 31 and $40(22,6 \%)$ and above $41(9,1 \%)$. Educational level was asked to participants and primary school $(9,1 \%)$, high school $(30,1 \%)$, university $(52,7)$ and lastly (master / doctorate $8,1 \%$ ). Organizational status of participants are classified as employee $(50,5 \%)$, specialist $(27,4 \%)$, supervisor $(17,7 \%)$ and manager $(4,3 \%)$.

\section{Factor Analysis of WBQ}

Factor analysis with principal component by varimax rotation, that was performed to find out the factor structure, revealed 9 factors. Because some items were below 0.45 or having collinearity with more than one factor, and some factors contain one item it was continued to perform factor analyzing by removing the items one by one till the ideal table. And totally 13 items removed, rest of the items naturally revealed 5 factors. The five factor and rested items explained 60,394 \% of the total variance. Kaiser-Meyer-Olkin Measure of Sampling result was .855 (>.70) and significance level was $\mathrm{p}=.00(<.05)$, Bartlett's Test of Sphericity value was found $1877.618(\mathrm{df}=253)$ so the result was acceptable. 5 factors found as; 1) organizational measures, 2) isolating and humiliating behaviors 3 ) physical violence 4) verbal violence 5) attacking on personal attributes parallel to literature. All factors' factor loadings and variance values are can be seen in Table 1. And reliability results of the factors are acceptable (Table 2). WBQ original version removed some items as we do. And when looked into international researches, Leymann found in a sample 4 and in other 5 category, Zapf 
found 7 category, Einarsen et al reported 5 category, and they agreed on 6 category but as it is stated, while some categories can be in some cases, some are not, because of cultural reasons or just about sample (Einarsen, Hoel, Zapf, Cooper, 2002, p.120).

\section{Table 1: Alpha Reliability Scores of WBQ}

\begin{tabular}{|l|l|l|}
\cline { 2 - 3 } \multicolumn{1}{c|}{} & Cronbach's Alpha & N of Items \\
\hline Factor 1: Organizational Measures & .888 & 10 \\
\hline Factor 2: Isolating and Humiliating Behaviors & .737 & 5 \\
\hline Factor 3: Physical Violence & .742 & 2 \\
\hline Factor 4: Verbal Violence & .629 & 3 \\
\hline Factor 5: Attacking on Personal Attributes & .592 & 3 \\
\hline
\end{tabular}

Table 2: Factor Analysis of Workplace Bullying Questionnaire

\begin{tabular}{|c|c|c|}
\hline \multicolumn{2}{|c|}{ Factor 1: Organizational Measures: } & \% variance: $22,378 \%$ \\
\hline Item No & Content & $\begin{array}{l}\text { Item } \\
\text { Loadings }\end{array}$ \\
\hline 26 & I am obliged to do meaningless tasks. & .820 \\
\hline 27 & I am ordered to do pointless tasks. & .779 \\
\hline 25 & I am ordered to work overtime. & .732 \\
\hline 29 & I am ordered to work above my capacity level. & .717 \\
\hline 22 & I am ordered to work above my physical capacity level. & .715 \\
\hline 19 & My efforts directed to work have not been taken into consideration. & .689 \\
\hline 30 & At my workplace, I am exposed to verbal violence. & .656 \\
\hline 28 & AlthoughI deserve, I am not gett ing upgraded. & .535 \\
\hline 1 & I am restricted to reach information necessary for my work. & .532 \\
\hline 4 & My works are not being appreciated. & .467 \\
\hline \multicolumn{2}{|c|}{ Factor 2: Isolating and Humiliating Behaviors: } & \% variance: 11,325 \\
\hline Item No & Content & $\begin{array}{l}\text { Item } \\
\text { Loading }\end{array}$ \\
\hline 7 & Appropriateness of my age to my work is being judged. & .738 \\
\hline 6 & I am critici zed for working little. & .638 \\
\hline 10 & At my workplace, I feel externalized. & .608 \\
\hline 24 & I am not given responsibility about my work tasks. & .588 \\
\hline 18 & My decisions about work are questioned. & .507 \\
\hline \multicolumn{2}{|c|}{ Factor 3: Physical Violence: } & \% variance: $9,242 \%$ \\
\hline Item No & Content & $\begin{array}{l}\text { Item } \\
\text { Loading }\end{array}$ \\
\hline 35 & At my workplace, I am exposed to physical violence. & .849 \\
\hline 36 & At my workplace, my physical characteristics and appearance are teased. & .731 \\
\hline \multicolumn{2}{|c|}{ Factor 4: Verbal Violence: } & \% variance: $8,61 \%$ \\
\hline Item No & Content & $\begin{array}{l}\text { Item } \\
\text { Loadings }\end{array}$ \\
\hline 23 & I am exposed to sexual (verbal, visual, physical, etc.) harassment. & .729 \\
\hline 34 & At my workplace, I receive aggressive telephone calls. & .687 \\
\hline 14 & At my workplace, I receive physical violence threats. & .674 \\
\hline \multicolumn{2}{|c|}{ Factor 5: Attacking on Personal Attributes: } & \% variance: $8,488 \%$ \\
\hline Item No & Content & $\begin{array}{l}\text { Item } \\
\text { Loadings }\end{array}$ \\
\hline 17 & Some of my personal attributes are being teased. & .607 \\
\hline 16 & I am critici zed about my religious and political views. & .547 \\
\hline 15 & There are rumors about me. & .496 \\
\hline
\end{tabular}




\section{Direction of Workplace Bullying}

Bullying behavior's direction are asked participants and commonly victims exposed to workplace bullying by supervisors and in some factors by colleagues; rarely subordinates are reported as bully. International researches generally report supervisor bullying is more prevalent (Vanderkerckhove, 2006). The results were pictured by mean values at Table 3 .

Table 3: Direction of WBQ mean results

\begin{tabular}{|c|c|c|c|c|c|c|c|c|c|}
\hline F1 & mean & F2 & mean & F3 & mean & F4 & mean & F5 & mean \\
\hline f1 sup. &, 2817 & f2 sup. &, 1409 & f3 sup. &, 0349 & f4 sup. &, 0358 & f5 sup. &, 0663 \\
\hline f1 col. &, 0731 & f2 col. &, 1215 & f3 col. &, 0565 & f4 col. &, 0556 & f5 col. &, 1470 \\
\hline f1 sub. &, 0172 & f2 sub. &, 0194 & f3 sub. &, 0134 & f4 sub. &, 0125 & f5 sub. &, 0430 \\
\hline
\end{tabular}

* sup. refers to supervisors; col. is colleagues and sub. infers subordinates

\section{Independent T-Test and One Way Anova Resuls for WBQ and Demographic Variables}

Gender: Whether gender is effective on being exposed to workplace bullying is investigated; independent samples t tests results didn't found any difference between genders and being exposed to workplace bullying; in literature most studies have reported fairly equal victimization rates for both men and women as well.

Age: One-way anova test was used for the variables when the difference was looked into the variable "age" and the five factor of WBQ. As it was seen from significance values, there was significance difference between dependent variable, the first factor, "organizational measures" $\mathrm{F}=8.325, \mathrm{p}=.00(<.05)$ and the independent variable; age (Table 4). But for the other factors of workplace bullying there was not any significant difference depending on age.

Table 4: One-way anova for organizational measures $\&$ age

\begin{tabular}{|l|l|c|c|c|c|c|}
\cline { 2 - 6 } \multicolumn{1}{l|}{} & Sum Of Squares & df & $\begin{array}{c}\text { Mean } \\
\text { Sguare }\end{array}$ & F & Sig. & \\
\hline Organizational Measures & Between Groups & 15.429 & 2 & 7.714 & 8.325 & \multirow{2}{*}{.000} \\
\hline & Within Groups & 169.571 & 183 & .927 & & \\
\hline & Total & 185.000 & 185 & & & \\
\hline
\end{tabular}

When the source of the difference for factor 1 (organizational measures) is investigated, Scheffe test shows (Table 5) that the difference between ages range 1 (below 30 and 30) and ages range 2 (the ages between 31-40) $\mathrm{p}=.003$ (<.05), mean value was .59919451, that was significant. And similarly there was significant difference for the first and third category (ages 41 and upper); $\mathrm{p}=.03$ and mean was found as .66393534. Age range 1, comparing to other age ranks, was significantly effective on being exposed to workplace bullying for the factor "organizational measures". That was the employee whose ages were below 30 was exposed bullying more than older ones. The same table shows at the same time that there was no significant difference for the other two age ranks. The 
significance between the other two age ranks were .973 (> .05) and mean values were .06474084 . As a result our Hypothesis was accepted. In the literature different results found about age; however Einarsen and Rankes (1997), Hoel and Cooper (2000) and Quine (1999) parallelly discovered that employees at young ages were at more risk of being a victim.

Table 5: Post hoc test for organizational measures \& age

\begin{tabular}{|c|c|c|c|c|c|c|c|}
\hline \multirow{7}{*}{$\begin{array}{l}\text { Organizational } \\
\text { Measures }\end{array}$} & (I)age & (j)age & Mean Difference(I-j) & Std.error & Sig. & Lower Bound & Upper Bound \\
\hline & \multirow{2}{*}{1} & 2 & $.59919451 *$ & .17134330 & .003 & .1763331 & 1.0220559 \\
\hline & & 3 & $.66393534 *$ & .24860233 & .030 & .0504049 & 1.2774658 \\
\hline & \multirow{2}{*}{2} & 1 & $-.59919451 *$ & .17134330 & .003 & -1.0220559 & -.1763331 \\
\hline & & 3 & .06474084 & .27671148 & .973 & -.6181607 & .7476424 \\
\hline & \multirow{2}{*}{3} & 1 & $-.66393534 *$ & .24860233 & .030 & -1.2774658 & -.0504049 \\
\hline & & 2 & -.06474084 & .27671148 & .973 & -.7476424 & .6181607 \\
\hline
\end{tabular}

*.The mean difference is significant at the .05 level

Participants ages were defined in three dimension in the analysis; age ranks 1 refers to: the ages 30 and below 30, 2 refers to the ages between 31 and 40 and the 3 was defined the ages 41 and upper 41 .

Educational Level: One-way anova results for "organizational measures", "isolating and humiliating behaviors", "verbal violence" from the dependent variables was statistically insignificant ( $p>.05$ ), results shows that being exposed to workplace bullying didn't changed due to educational level for these factors (factor 1,2,4). However the significance for "physical violence" was $\mathrm{p}=.006$ $(<.05)$ and $\mathrm{F}=4.316$ shows that this factors of workplace bullying was effected from educational level (Table 6). When looking to Post Hoc test results (Table 7) the difference was seen in detailed. There was statistically significant difference for the dependent variable "physical violence" between the educational level 1(primary school), and educational level 2 (high school), $\mathrm{p}=.014$ (<.05), $\mathrm{F}=.89354137$. And educational level 1 and educational level 3(university level) was considerably different $\mathrm{p}=.011, \mathrm{~F}=.86585189$ but there was not a significant difference between educational level 1 and educational level 4 (master/doctorate level). As a result, it could be said that being at primary school level employee was significantly effective on being exposed to workplace bullying in the factors "physical violence" comparing to being both in high school and university level but not being at master or doctorate level.

\section{Table 6: One-way anova for physical violence, attacking on personal attributes \& education}

\begin{tabular}{|c|c|c|c|c|c|c|}
\hline & Sum Of Squares & df & $\begin{array}{l}\text { Mean } \\
\text { Sguare }\end{array}$ & $\mathrm{F}$ & Sig. & \\
\hline \multirow[t]{3}{*}{ Physical Violence } & Between Groups & 12.288 & 3 & 4.096 & 4.316 & .006 \\
\hline & Within Groups & 172.712 & 182 & .949 & & \\
\hline & Total & 185.000 & 185 & & & \\
\hline \multirow[t]{3}{*}{ Attacking on Personal Attributes } & Between Groups & 11.846 & 3 & 3.949 & 4.150 & .007 \\
\hline & Within Groups & 173.154 & 182 & .951 & & \\
\hline & Total & 185.000 & 185 & & & \\
\hline
\end{tabular}

One-way Anova results for factor 5, "attacking on personal attributes" (Table 6) were; $p=.007$ $(<.05)$ and $\mathrm{F}=4.150$ shows significance difference for this dimension; when looking into the Post Hoc results, the source of the difference could be seen (Table 7). The values between educational level 2 (high school level) and educational level 3 (university level) $\mathrm{p}=.037$ and $\mathrm{F}=.48117694$. 
There was significant difference between the high school and university level employee on being exposed to workplace bullying on "attacking on personal attributes" factor, high school level employees are being exposed to workplace bullying more than university levels. But the other $\mathrm{p}$ and $\mathrm{F}$ values for primary and master / doctorate level employee didn't point to a significant difference between any variable for the "attacking on personal attributes".

Table 7: Post hoc test for physical violence, attacking on personal attributes \& education

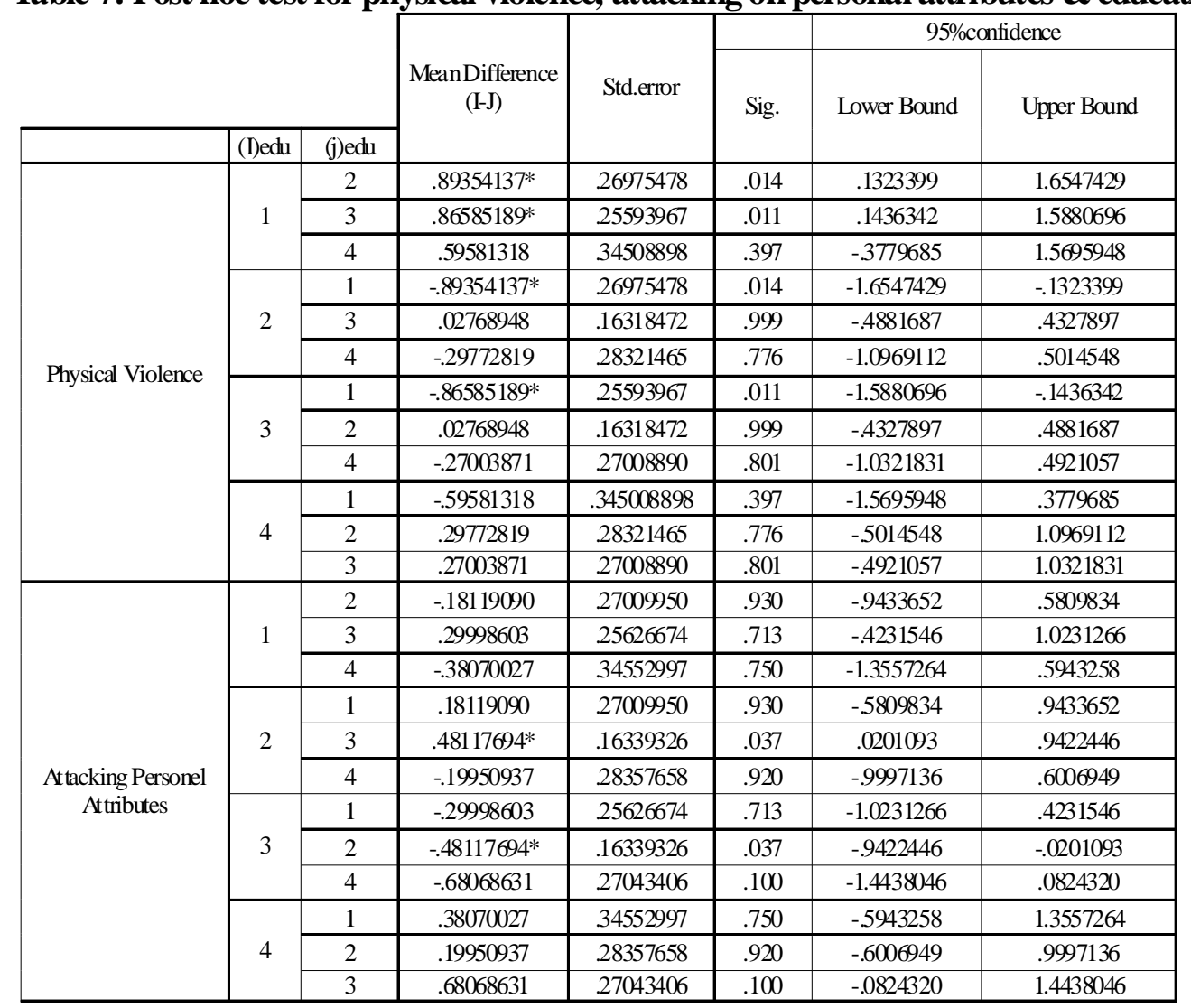

*The mean difference is significant at the. 05 level.

Educational level was defined in 4 categories; and numbers from 1 to 4 given in the analysis for these categories; number 1 refers to Primary school, 2 was used for High school, 3 was for University and 4 refers to Master or Doctorate level.

Organizational status: Because all significance values at .05 confidence level was $>.05$ there was no difference for WBQ factors depending on organizational status, that is not effective on being exposed to workplace bullying according to one-way Anova results. Literature indicates different results for organizational status, the differences with regard to hierarchical position were not statistically significant (Leymann, 1992a) in parallel with our findings.

Gender, age, educational level and organizational status are investigated for demographic hypothesis for the study. Some demographic variables such as age and educational level there are significant differences, so our hypothesis " $\mathrm{H}_{1}$ : There is any difference depending on demographic variables in being exposed to workplace bullying" is accepted.

Forming EPQR-A: The items of EPQR-A were calculated by compute method. The internal consistency, test-retest reliability and construct validity of the questionnaire was done by Karanc1 et al. in 2007 and found acceptable the values for using the scale. Because the questionnaire was designed as yes-no format, for the reliability Kuder-Richardson 20 method was used. KuderRichardson alpha values were seen in the table 8 . The alpha values of the original Turkish version was compared to the study's result and extroversion factor was KR-20 $=.78$ (our result was .845), lie 
was .64 (our result was equally .644), neuroticism was found .65 (our finding was .691), and finally psychoticism factor result was .42 (our result was .549), this refers to validity of our study. The psychoticism factor reliability result wasn't found higher, as well as the other studies done other countries (Francis et al. 1992, Katz \& Francis 2000, Lewis et al. 2002, Karanc1 et al. 2007). Because of generally lower results, the reason was thought to be because of expressions could be insufficient, that was not about translation (Karanc1, 2007, p.7) in this study reliability coefficients are found acceptable for analysis.

\section{Table 8: Alpha Reliability Scores of EPQR-A}

\begin{tabular}{|l|l|l|}
\cline { 2 - 3 } \multicolumn{1}{c|}{} & Kuder-Richardson alpha & N of Items \\
\hline Factor 1: Extroversion & .845 & 6 \\
\hline Factor 2: Lie & .644 & 6 \\
\hline Factor 3: Neuroticism & .691 & 6 \\
\hline Factor 4: Psychoticism & .549 & 6 \\
\hline
\end{tabular}

\section{Correlation Analysis for WBQ factors and EPQR-A sub-scales}

Lastly correlation analysis was done to analyze the main hypothesis; the five factor of WBQ and three subscale of EPQR-A was analyzed for a statistical relation between the variables; results shows that three factors of WBQ (factor 2, 3 and 5) and EPQR-A subscales didn't refer to any significant correlation.

As it can be seen in Table 9, neuroticism and first factor of WBQ correlation, $\mathrm{p}=.00(<.05), \mathrm{r}=.302$. There was a correlation between the factor 1 "organizational measures" and neuroticism. Being exposed to workplace bullying by organizational measures and being a neurotic person is positively related to each other. It can be said as well, neurotic people are exposed to such behaviors more than others. This is parallel to some empirical studies (Varita 1996) and as found in school bullying (Byrne, 1994; Maynard \& Joseph, 1997; Slee \& Rigby, 1993). In addition to this, factor 4 "verbal violence" and psychoticism results referred to statistically significant $\mathrm{p}=.003(<.05)$, positive and strong relationship $\mathrm{r}=.214$ (Table 9). So being a psychotic person and being exposed to verbal violence are in relation with each other.

The results suggest that personality traits may explain why such people target to workplace bullying or which type personality defines such behaviors as workplace bullying. In literature studies about workplace bullying are done with different scales at different dimensions, as far as we reached, because EPQR-A hasn't been used for the relation of workplace bullying, preferred for the study. The other most known scales 16 PF, Five-Factor Model and MMPI-2 were used by the researchers. But to sum up neuroticism is found as affective personality type as well as psychoticism. Our main hypothesis accepted in this condition, " $\mathrm{H}_{1}$ : There is a significant relationship between personality and being exposed to workplace bullying or mobbing. A simple figure is illustrated in the following in order to summarize the correlations. 
Table 9: Correlation Results for Scales

\begin{tabular}{|l|c|c|c|}
\cline { 2 - 4 } \multicolumn{1}{l|}{} & Extroversion & Neuroticism & $\begin{array}{c}\text { Psychoti- } \\
\text { cism }\end{array}$ \\
\hline F1: Organizational Measures &, 021 &, $\mathbf{3 0 2}$ &, 042 \\
\hline F2: Isolating and Humiliating Behaviors &, 037 &, 074 &, 031 \\
\hline F3: Physical Violence &,- 115 &, 119 &, 037 \\
\hline F4: Verbal Violence &, 043 &, 101 &, $\mathbf{2 1 4}$ \\
\hline F5: Attacking on Personal Attributes &,- 061 &,- 054 &, 117 \\
\hline
\end{tabular}

Sig. (2-tailed) $\mathrm{p}<.001=* * ; \mathrm{p}<.05=*$; boldface indicates significant correlations between variables.

\section{CONCLUSION}

Personality can be affective because of being subjective; while someone feels being exposed to workplace bullying by a behavior type, some other feels nothing that is, find natural the behavior; the important thing in that position is, what is felt. Because all psychological unwanted results is occurs because we felt like that, no matter what is done to us if we didn't affected from the behavior. Because everybody is part of the society and being healthy is due to every circle of the chain, every one of us is part of the problem; while someone is source, some other one is solution; some is affected directly or someone's husband effect; some is alone in the difficult situation, some loose his/ her family, friends and the most importantly looses health; moreover life. While the results are such serious, all factors should be taken into consideration.

It can be said from this study that, it is possible to be a relation between personality and being exposed to workplace bullying. Studies about personality of victims' found different results but they assess from different aspects as well. And bully's personality hasn't been studied empirically. Future studies can investigate both victim's and bully's personality, a universal scale can be developed for workplace bullying behavior. Because victims' and bullies' personalities determine the type of behavior according to some researches "type of workplace bullying" can be investigated. The researchers are in the process of designing a commercial tool will be able to identify those most at risk of workplace bullying. By being able to identify these people, managers will be able to ensure that individuals are suitably supported by the organization; Personality results could be helpful for placing the employee to the suitable department according to risk of being exposed to workplace bullying too, so this knowledge can be helpful for healthy employee and decreasing negative atmosphere in the organization in today's and tomorrow's work life. 


\section{REFERENCES}

Australasian Centre for Policing Research (ACPR), "Workplace Bullying: Implications for Police Organizations", paper series nu.8.

Berdahl, Jennıfer L., "Harassment Based On Sex: Protecting Social Status in the Context of Gender Hierarchy", (641-658), Academy of Management Review, Vol. 32, No. 2, 2007.

Beswick, Johanna, Joanne Gore, David Palferman (HSE), "Bullying at Work: a Review of the Literature", Health and Safety Laboratory, Harpur Hill: Buxton, 2006.

Blase, Joseph, "The Dark Side of Leadership: Teacher Perspectives of Principal Mistreatment” ,Educational Administration Quarterly, (671-727), Vol. 38, No. 5, December 2002 .

Coyne, Iain, Elizabeth Seigne, Peter Randall, "Predicting Workplace Victim Status from Personality", (335- 349), European Journal of Work and Organizational Psychology, vol. 9 (3), 2000.

Davenport, Noa, Ruth Distler Schwartz, Gail Pursell Eliot, Mobbing: Emotional Abuse in the American Workplace, Ames, Iowa: Civil Society Publishing, 2000.

Dikmen, Ayşe, "Workplace Mobbing/ Bullying and Its effects on Intention to Leave the Organization”, (Master Thesis, Marmara University, Social Sciences Institute, 2005).

Douglas, Elaine, Bullying in the Workplace: An Organizational Toolkit, Gower Publishing Ltd, 2001.

Einarsen, S, Skogstad, A (1996), "Prevalence and risk groups of bullying and harassment at work'", European Journal of Work and Organisational Psychology, Vol. 5 pp.185-202.

Einarsen, Ståle, Helge Hoel, Dieter Zapf, Carly L. Cooper, Bullying and Emotional Abuse in the Workplace: International Perspectives in Research and Practice, CRC Pres, 2003.

Einarsen, Stale, Helge, Hoel, Dieter Zapf, Cary L. Cooper, Bullying and Emotional Abuse in the Workplace: International , 2002, CRC Press.

Ewen, Robert B., Personality, a Topical Approach: Theories, Research, Major Controversies, Lawrence Erlbaum Associates, 1998.

Eysenck, H. J, S. B. G Eysenck, "The Eysenck Personality Questionnaire, London: Hodder \&Stoughton,1975”, This Week's Citation Classic, CC/Number 22,may 28, 1990.

Forrest, Sarrah, Christopher Alan Lewis, Mark Shevlin, "Examining the Factor Structure and Differential Functioning of the Eysenck Personality Questionnaire Revised- Abbreviated", Personality and Individual Differences, Pergamon, (579-588), vol. 29, 2000.

Fox, Suzy, Lamont E. Stallworth, "Racial/Ethical Bullying: Exploring Links between Bullying and Racism in the US Workplace*”, Journal of Vocational Behavior, (438-456), vol.66, 2005.

Francis, Leslie J., Chris J. Jackson, "Which version of the Eysenck Personality Profiler is best? 6-, 12- or 20-items per scale", Personality and Individual Differences, Science Direct, (1659-1666), vol. 37, 2004.

Hodson, Randy, Vincent J. Roscigno, Steven H. Lopez " "Chaos and The Abuse of The Power: Workplace Bullying in Organizational and Interactional Context", (382- 416), Work and Occupations, vol. 33, nu. 4, 2006.

Leymann, Heinz, "The Mobbing Encyclopedia, Bullying; Whistleblowing, "Identification of Mobbing Activities", (http://www.leymann.se/English/frame.html). 
Martin, Brian, "Activists and "difficult people"”, Social Anarchism, (27-47), nu.30, 2001.

Matthiesen, Stig Berge, Stale Einarsen, "MMPI-2 Configurations among Victims of Bullying at Work", (467-484), European Journal of Work and Organizational Psychology, vol. 10 (4), 2001.

Notelaers, Guy, Stale Einarsen, Hans de Witte, Jersen K. Vermunt, "Measuring Exposure to Bullying at Work: The Validity and Advantages of the Latent Class Cluster Approach", (288-301), Work \& Stress, 20(4), October-December 2006.

Nuray Karanc1, Gülay Dirik, Orçun Yorulmaz,"Eysenck Kişilik Anketi- Gözden Geçirilmiş Kısaltılmış Formu'nun (EKA-GGK) Türkiye'de Geçerlilik ve Güvenilirlik Çalışması”, Türk Psikiyatri Dergisi, 2007, 18 (3).

Randle, Jacqueline, Workplace Bullying in NHS, Radcliffe Publishing, 2006.

Rayner, Charlotte, Helge Hoel, “A Summary Review of Literature Relating to Workplace Bullying”, (181-191), Journal of Community \& Applied Social Psychology, Vol. 7, 1997.

Richards, Helen, Sheila Freeman, Bullying in the Workplace: An Occupational Hazard, India: Leads Press.

Ryckman, Richard M., Theories of Personality, $7^{\text {th }}$ ed., USA: Wadsworth, 2000.

Salin, Denise, "Workplace Bullying among Business Professionals: Prevalence, Gender Differences and the Role of Organizational Politics", Pistes, vol7, no3, November 2005.

Salin, Denise, "Workplace Bullying Among Business Professionals: Prevalence, Organizational Antecedents and Gender Differences", Ekonomi Och Samhalle, Swedish School of Economics and Business Administration, Helsingfors, nu.117, 2003.

Sandvik, Pamela Lutgen, Sarah J. Tracy, Jess K. Alberts, "Burned by Bullying in the American Workplace: Prevalence, Perception, Degree and Impact*", Journal of Management Studies, vol. 44:6, September 2007.

Shin, Hwayeon Helene, "Institutional safe space and shame management in workplace bullying", (The Degree of Doctor Thesis, Australian National University, Philosophy, December 2005).

Tehrani, Noreen, "Bullying at Work: Beyond Policies to a Culture of Respect", Chartered Institute of Personnel and Development (cipd), 2005.

Vanderkerckhove, Wim, Whistleblowing and Organizational Social Responsibility: A Global Assessment, Ashgate Publishing Ltd., 2006.

Westhues, Kenneth, "Ten Choices in the Study of Workplace Mobbing or Bullying", Fifth International Conference on Workplace Bullying, Trinity College, Dublin, (15-17 June 2006), (http://arts.uwaterloo.ca/ kwesthue/dublin.htm). 